\title{
ANCHIALINE ECOSYSTEMS
}

\section{Preface}

\author{
Carol Wicks · William F. Humphreys
}

Published online: 25 August 2011

(C) Springer Science+Business Media B.V. 2011

Around the world, in island and near coastal regions, researchers have been working to characterise the attributes of anchialine ecosystems: where they occur, what they comprise, the origin of the fauna, how they function and their vulnerabilities. The inaugural interdisciplinary symposium on anchialine ecosystems was organized around a schema (Fig. 1) aimed to draw together scientists and to foster research collaboration in this demanding ecosystem. The aim of the symposia was to review current knowledge of anchialine ecosystems in an environment that facilitated exchange of

Guest editors: C. Wicks \& W. F. Humphreys / Anchialine Ecosystems: reflections and prospects

C. Wicks $(\bowtie)$

Department of Geology and Geophysics, Louisiana State University, Baton Rouge, LA, USA

e-mail: cwicks@1su.edu

C. Wicks

Karst Waters Institute, PO Box 4142, Leesburg,

VA 20177, USA

\section{W. F. Humphreys}

Department of Terrestrial Zoology, Western Australian Museum, Welshpool, WA, Australia

\section{W. F. Humphreys}

School of Animal Biology, University of Western

Australia, Crawley, WA, Australia

W. F. Humphreys

School of Earth and Environmental Sciences,

The University of Adelaide, SA, Australia ideas with people from disparate disciplines. It was intended to facilitate the development of coordinated research directions and to promote awareness of the biodiversity conservation implications of anchialine systems.

What is peculiar to anchialine systems, which have persisted apparently through geological eras, that has allowed the persistence within this marginal ecosystem of a large number of higher taxa, particularly crustaceans, that are biogeographic and/or phylogenetic relicts (Iliffe, 1992). These commonly display extraordinary disjunct distributions but whose overall composition is predictable however far apart in the world they occur (Jaume et al., 2001). This applies to anchialine systems of epicontinental regions, and those on isolated seamounts, although the faunal assemblage differs between the two (Humphreys \& Danielopol, 2006; Humphreys et al., 2009b).

Anchialine ecosystems, which, by definition, have no surface connection with the ocean, occur in near coastal groundwater affected by marine tides, typically in karst but also in pseudokarst such as lava flows, and fractured rock. The coastal location of anchialine systems, and their global distribution in mediterranean to peritropical climates, single out the areas for development, especially for tourism, often intense, with implications for the persistence of many anchialine systems through pollution and loss of habitat (Chai et al., 1989).

This Special Issue of Hydrobiologia is an outgrowth of the "Anchialine Ecosystems: Reflections 
Fig. 1 Schema denoting various attributes of anchialine systems around which the contributions to the symposium were sought (developed by W. Humphreys 2008)

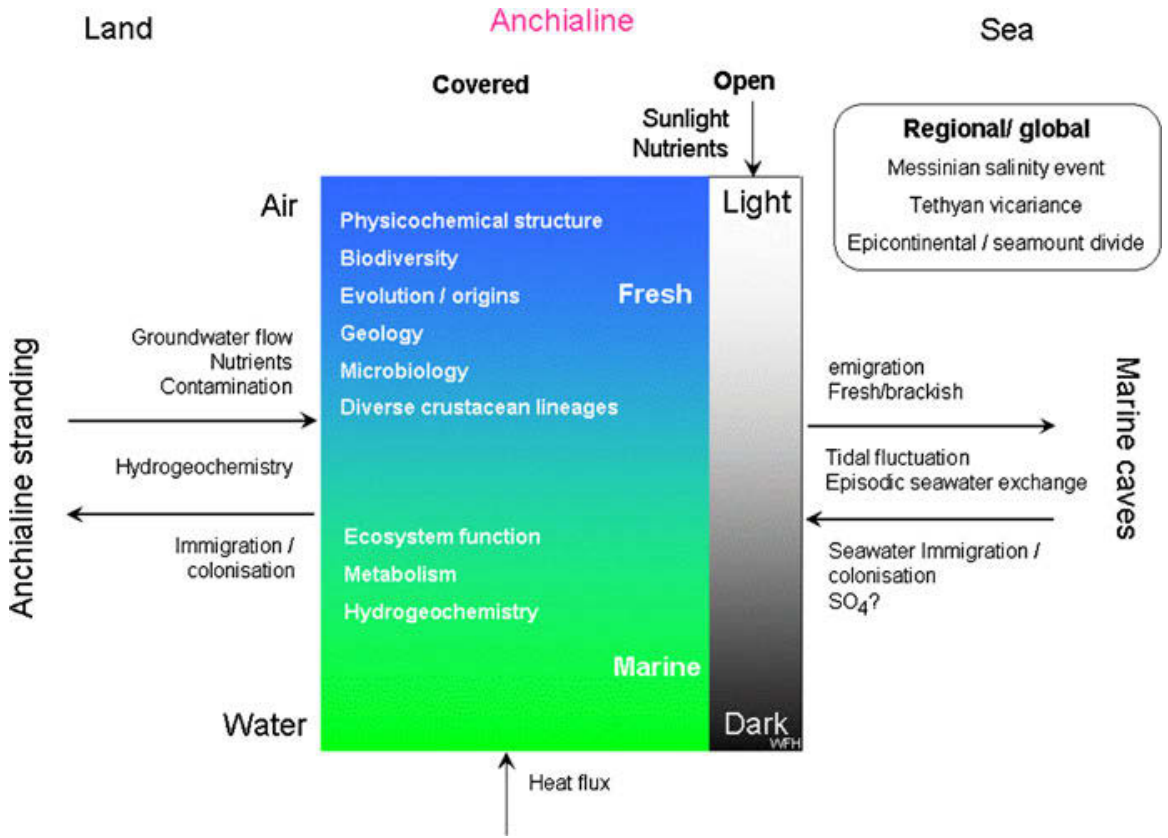

and Prospects" (Humphreys et al., 2009a) symposium sponsored by the Karst Waters Institute, the Mediterranean Institute for Advanced Studies, and the Western Australian Museum. This inaugural symposium was held in Palma de Mallorca, Balearic Islands, Spain, in November 2009. At the symposium, there were 32 technical talks, seven posters, and opening and closing remarks. Several of the presenters chose to submit their work to Hydrobiologia for inclusion in the Special Issue.

From the Symposium, three research directions emerged:

(1) Linking the timing of geologic events to biological events is critical if we are to understand how the unique anchialine ecosystems evolved.

(2) Linking geochemical processes to biological processes is critical if we are to understand controls on community composition and species distribution patterns.

(3) Linking physiological processes to ecological processes is critical if we are to understand how the animals function in changing (tidal cycle) environment.

These directions are covered within the articles in this Special Issue of Hydrobiologia.

\section{References}

Chai, D. K., L. W. Cuddihy, \& C. P. Stone, 1989. An Inventory and Assessment of Anchialine Pools in Hawaii Volcanoes National Park from Waha'ula to Ka'aha, Puna and Ka'u, Hawaii. Technical Report 69. Cooperative National Park Resources Studies Unit, University of Hawaii, Honolulu: 37 pp.

Humphreys, W. F. \& D. L. Danielopol, 2006. Danielopolina (Ostracoda, Thaumatocyprididae) on Christmas Island, Indian Ocean, a sea mount island. Crustaceana 78: 1339-1352.

Humphreys, W., D. Jaume, C. Wicks, R. Price, 2009a. Proceedings from Anchialine ecosystems: reflection and prospects, 17-20 November 2009, Mediterranean Institute for Advanced Studies, Palma de Mallorca, Spain: 62 pp.

Humphreys, W. F., L. S. Kornicker \& D. L. Danielopol, 2009 b. On the origin of Danielopolina baltanasi sp. n. (Ostracoda, Thaumatocypridoidea) from three anchialine caves on Christmas Island, a seamount in the Indian Ocean. Crustaceana 82: 1177-1203.

Iliffe, T. M., 1992. Anchialine cave biology. In Camacho, A. I. (ed.), The Natural History of Biospeleology. Mongrafias del Museo Nacional de Ciencias Naturales, Madrid: 614-636.

Jaume, D., G. A. Boxshall \& W. F. Humphreys, 2001. New stygobiont copepods (Calanoida; Misophrioida) from Bundera sinkhole, an anchialine cenote on north-western Australia. Zoological Journal of the Linnean Society, London 133: 1-24. 